\title{
MATERIAŁY
}

Krzysztof Osóbka

DOI: 10.14746/bhw.2017.37.7

Biuro UAM ds. Studentów z Niepetnosprawnościami

Uniwersytet im. Adama Mickiewicza w Poznaniu

\section{Historia autyzmu od baśni i legend po badania genetyczne - laboratorium budowy mitów w nauce}

\begin{abstract}
History of autism from fairy tale and legends after genetic research - a laboratory of building scientific myths

Autism is one of the most mysterious human disorders ever known. Although existing since the dawn of humanity, it was only in 1943 that science took up this subject. Before, undiscovered and unnamed, it was considered merely a legend, and the only existing records were those of a few pioneer case studies.

With his discoveries, Leo Kanner, the first person to properly define autism, marked the beginning of a struggle to describe the disorder using scientific language. Unfortunately, the attempts were not always successful. Autism, as described by contemporary science, is a neurodevelopmental disorder. Theories claiming its psychogenic aetiology can no longer be sustained.

The history of research concerning autism points to a phenomenon known as collective thinking a term coined by Ludwik Fleck, as well as to the process of the emergence of a scientific myth. It is a study of how researchers' presuppositions can shape social beliefs, and at the same time how constructing scientific theories is inherently ingrained in the cognitive style of an era.

The second half of the $20^{\text {th }}$ century marks the beginning of a gradual change in the classification of autism. The perception of the nature of this disorder shifted from psychogenic theories to organic aetiologies.

It is the voice of the enormously talented and creative individuals with high-functioning autism that triggered a breakthrough in the research - a voice that was ignored until the 1980s.
\end{abstract}

Keywords: autism history, Leo Kanner, autism causes, psychoanalysis, neurodevelopmental disorder, collective thinking, Louis Fleck, scientific myth, classification dsm, high-functioning autism 


\section{Wstęp}

W 1943 r. amerykańskie czasopismo medyczne „The Nervous Child” opublikowało artykuł pediatry Leo Kannera pt. Zaburzenia autystyczne kontaktu afektywnego (Autistic Disturbances of Affective Contac). Liczący 33 strony kazuistyczny opis 11 przypadków dzieci dał początek systematycznie rosnącemu zainteresowaniu nauki - niedostrzegalnymi dla niej dotąd - niezwykłymi zaburzeniami rozwoju u dzieci ${ }^{1}$.

Koncepcje istoty i etiologii autyzmu przeszły od tego czasu wielką ewolucję, ale praca austriackiego pediatry zachowuje swoje doniosłe znaczenie dla psychiatrii dziecięcej i przytaczana jest niemal we wszystkich publikacjach na ten temat ${ }^{2}$.

L. Kanner określił zaburzenia u opisywanych dzieci jako „wrodzone”, jednak ze względu na fakt, że dużo uwagi poświęcił opisowi rodziców, których przedstawił jako intelektualistów, zimnych $i$ sztywnych, badacze z nurtu psychoanalitycznego bardzo szybko ustalili związek między cechami rodziców a autyzmem³ ${ }^{3}$ Mimo iż nie było żadnych dowodów na istnienie takiej zależności, poglądy te przyjęli w zasadzie wszyscy profesjonaliści. Psychoanlitycznej indoktrynacji uległy też całe pokolenia rodziców, wierząc, że są sprawcami zaburzenia swojego dziecka ${ }^{4}$. Psychogenne teorie dotyczące etiologii autyzmu nie znalazły żadnego oparcia w badaniach empirycznych. Przyniosły jedynie niepotrzebne nieporozumienia i ogromne cierpienia zarówno dzieciom autystycznym, jak i rodzicom, którzy odegrali rolę kozła ofiarnego. Terapia oparta na założeniach psychodynamicznych okazała się całkowicie nieskuteczna 5 .

Dopiero trzecia wersja klasyfikacji DSM-III z roku 1980 zaklasyfikowała autyzm do całościowych zaburzeń rozwoju, formalnie odróżniając dzieci z autyzmem od psychotycznych lub schizofrenicznych ${ }^{6}$. Najnowsza wersja wymienionej klasyfikacji - DSM-V - rezygnuje z terminu całościowe zaburzenia rozwoju i posługuje się terminem zaburzenia ze spektrum autyzmu (Autism Spectrum Disorders - w skrócie ASD), które uważane jest za zaburzenie neurorozwojowe z symptomami widocznymi od wczesnego dzieciństwa?

Dlaczego spekulatywne teorie, niedające szans na jakąkolwiek skuteczną terapię przez kilkadziesiąt lat istniały i były rozwijane w kręgach naukowych? Z jakich powodów pionierska praca L. Kannera była wybiórczo odczytywana, a doniesienia potwierdzające organiczne podłoże zaburzenia były ignorowane?

Historia autyzmu ujawnia, jak silnie nauka uwikłana jest w kontekst i styl myślowy swojej epoki, a jej wytwory mogą ulegać mitologizacji.

${ }^{1}$ A. i F. Brauner, Dziecko zagubione w rzeczywistości: historia autyzmu od czasów baśni o wróżkach. Fikcja literacka i rzeczywistość kliniczna, Warszawa 1988, s. 11.

2 Ibidem, s. 197.

3 Ibidem, s. 218.

${ }^{4}$ L. Bobkowicz-Lewartowska, Autyzm dziecięcy - zagadnienia diagnozy i terapii, Kraków 2000, s. 11.

5 Ibidem, s. 27.

${ }^{6}$ T. Gałkowski, Usprawnienie dziecka autystycznego w rodzinie, Warszawa 1980, s. 7.

7 J. Morrison, DSM-5 bez tajemnic. Praktyczny Przewodnik dla klinicystów, Kraków 2016, s. 40. 
Celem tego artykułu jest przedstawienie obecnych w historii badań nad autyzmem, psychospołecznych procesów, nazwanych przez Ludwika Flecka kolektywem myślowym oraz konstrukcji silnie utrwalonego wśród specjalistów mitu naukowego na temat przyczyn autyzmu.

Aby cel ten osiągnąc trzeba odwołać się do źródeł starszych niż praca L. Kannera, w których można odnaleźć ślady autyzmu, a następnie prześledzić kontekst powstania pracy pediatry oraz jej dalsze losy. Kluczowym zagadnieniem będzie tu jednak analiza konstrukcji teorii o psychogennej etiologii autyzmu, w szczególności koncepcji psychiatry Brunona Bettelheima.

W dalszej części pracy - dla zobrazowania nietrafności dociekań nurtu psychoanalitycznego - zostaną pokrótce zarysowane najważniejsze aktualne kwestie związane z zakłóceniami w neurorozwoju leżące u podłoża autyzmu.

Przemiany w postrzeganiu przyczyn autyzmu skutkowały zmianami w sposobie jego klasyfikowania oraz jego stopniową demitologizacją. Zdaniem autora, ostatecznym argumentem na rzecz tezy o fałszywości wszelkich poglądów o psychogennej naturze zaburzenia jest głos wysokofunkcjonujących osób z autyzmem, który zamyka niniejsze rozważania o historii autyzmu.

\section{Otchlanie czasu przed Kannerem}

W lipcu 1969 r. na I Kongresie Krajowego Stowarzyszenia dla Dzieci Autystycznych w San Francisco L. Kanner powiedział: Nie odkrytem autyzmu. Istniat on już dawniej. Nawet nie musiatem się specjalnie wysilać, by go wykryć8. Skoro istniał już dawniej, musi być po nim jakiś ślad - jeśli nie w nauce, to w opisach literackich, kulturze, podaniach. I rzeczywiście istnieje. Opisy „przedziwnych” zachowań dzieci, niedających się wyjaśnić głuchotą, obniżoną sprawnością umysłową czy jakąkolwiek znaną chorobą, zawarte są w legendach, baśniach i podaniach historycznych, sięgających nawet starożytności. Oczywiście nie można stwierdzić z całą pewnością, że jakiekolwiek z nich stanowi opis któregoś ze złożonych zaburzeń neurorozwojowych, które dziś - według klasyfikacji $D S M-V$ - klasyfikuje się jako spektrum zaburzeń autystycznych ${ }^{9}$. Jednak pewne charakterystyczne dla autyzmu zachowania, utrwalone w tych relacjach - np. specyficzne zaburzenie mowy - pozwalają domniemywać, że opisują właśnie dzieci z zaburzeniami z kręgu autyzmu.

Poszukiwaniami śladów autyzmu sprzed jego „ujawnienia” przez Kannera zajmowali się Alfred i Francoise Brauner, opisując wiele z nich w książce Dziecko zagubione w rzeczywistości: historia autyzmu od czasów baśni o wróżkach. Fikcja literacka i rze-

\footnotetext{
${ }^{8}$ Leo Kanner, wypowiedź ustna, posiedzenie Amerykańskiego Stowarzyszenia dla Dzieci Autystycznych, [cyt. za:] Brauner A. i F., op. cit., s. 2.

${ }^{9}$ J. Morrison, op. cit., s. 40.
} 
czywistość kliniczna. Ich praca ukazała się po raz pierwszy we Francji, w czasie gdy stosowano jeszcze w tym kraju terminy autyzm i psychoza dziecięca zamiennie $^{10}$.

Badacze historii autyzmu za pierwszą wzmiankę o osobie z zaburzeniem ze spektrum autyzmu uznają opis pozostawiony przez Herodota - greckiego historyka z V w. p. n. e. Według dziejopisa, Krezeus, król Lidyjczyków, miał dwóch synów. Starszy z nich, Artys, przerastał inteligencją wszystkich swoich rówieśników. Młodszy syn, którego imię pozostało nieznane, był głuchy i niemy, choć dobrze zbudowany pod każdym względem ${ }^{11}$. Zgodnie z przepowiednią wyroczni w Delfach, człowiek ten miał przemówić w dniu nieszczęścia.

„Człowieku, nie zabijaj Krezeusa!” - brzmiały pierwsze i jedyne słowa przez niego wypowiedziane, w chwili gdy perski żołnierz zbliża się, by zabić króla w dniu upadku jego państwa.

Jak sądzą A. i F. Braunerowie, ta nagła wypowiedź przypomina charakterystyczną dla niektórych osób z autyzmem „eksplozję językową” - nagłe pojawienie się mowy pod wpływem silnych emocji. Ponadto uznać należy, że opisany przez Herodota człowiek nie był głuchy, skoro wypowiedział przytoczone zdanie. Pomyłka greckiego historyka w tym względzie nie jest nieprawdopodobna - współcześnie zaznacza się konieczność jasnego odróżnienia braku mowy u dziecka wynikającego z głuchoty bądź autyzmu ${ }^{12}$. Obecnie znane jest też prawdopodobieństwo istnienia korelacji pomiędzy genami nieprawidłowości neurorozwojowych a genami szczególnych uzdolnień i ponadprzeciętnej inteligencji ${ }^{13}$, jaką przejawiał Artys - drugi z synów Krezeusa.

Nagła wypowiedź przypominająca autystyczną „eksplozję językową” i brat o ponadprzeciętnej inteligencji to za mało, by uznać syna Krezeusa za osobę z autyzmem, jednak szczegółowa analiza języka, jakim Herodot próbuje opisać tę postać sugeruje, że wymyka się on prostym pojęciom głuchoty czy opóźnionego rozwoju.

Zdaniem badaczy ${ }^{14}$, syn króla Krezeusa wydaje się być pierwszym opisanym, ale na pewno nie pierwszym w historii, przypadkiem dziecka z zaburzeniami z kręgu autyzmu.

Poszukując śladów autyzmu na przestrzeni wieków średnich trudno jest znaleźć opisy dzieci odchodzacych od normy pod względem psychicznym, poniewaz byly one uznawane po prostu za opóźnione $w$ rozwoju i najczesściej nie przeżywaty. Poza tym udział demona w tego typu urodzeniach byt zbyt oczywisty, by tracić czas na próby zrozumienia ich natury ${ }^{15}$.

Postawy ludzi reprezentujących wiedzę - teologów, filozofów, prawników - nie różniły się w tym względzie od innych. Na początku renesansu ciekawą relację przedstawił Marcin Luter:

10 T. Gałkowski, op. cit., s. 7.

11 A. i F. Brauner, op. cit., s. 65.

${ }_{12}$ T. Pietras, A. Witusik, Autyzm - pozycja nozologiczna, charakterystyka kliniczna i diagnoza, w: T. Pietras, A. Witusik, P. Gałecki (red.), Autyzm - epidemiologia, diagnoza i terapia, Wrocław 2010, s. 16-20.

13 T. Grandin, Myślenie obrazami oraz inne relacje z życia z autyzmem, Warszawa 2006, s. 226.

14 A. i F. Brauner, op. cit., s. 66.

15 Ibidem, s. 61. 
Bytem wstrzaśnięty, gdy przed 8 laty w Dessau ogląatem dziecko opętane przez Duchy. Miał oczy i kończyny takie jak wszystkie dzieci, lecz przez caty czas tylko jadt, pochłaniając tyle co dwóch wieśniaków lub żniwiarzy. Gdy chciano go kłaść spać, zaczynat krzyczeć. Gdy w domu zdarzało się jakieś nieszczęście, wtedy śmiat się i okazywał radość. Natomiast gdy wszystko szło jak należy, zaczynat płakać i zdawat się być głęboko zasmucony.

Powiedziałem wówczas księciu Antahalta, że jeśli ja byłbym na jego miejscu, jako władca naszego kraju, czułbym się usprawiedliwiony do zabicia takiej ludzkiej istoty i wrzucenia jej do Mołdawy. Jednocześnie zachęcatem ludzi z tego kraju, by prosili Boga goraco o uwolnienie ich od tego Diabła. I nastapiło to ponieważ na drugi rok dziecko zmarto. Moim zdaniem tego rodzaju dzieci stanowia jedynie mase mięsa pozbawiona duszy [podkr. K.O.] ${ }^{16}$

Dopiero 250 lat później powstał pierwszy naukowy opis chłopca o inicjale W.H., który zachowywał się w sposób bardzo podobny. Brytyjski lekarz John Haslam, który tego dokonał, nie wierzył już w Diabła tkwiącego w dziecku, lecz przyznawał, że jest zupełnie bezsilny wobec jego choroby. Swoje spostrzeżenia opublikował w obszernym dziele Obserwacje na temat obłędu i melancholii wraz z uwagami praktycznymi na temat tych chorób w roku 1809. Nie mógł wówczas wiedzieć, że dokonał pierwszego naukowego opisu przypadku zaburzenia ze spektrum autyzmu ${ }^{17}$. Zachowanie chłopca, spełniało wszystkie cztery kryteria diagnostyczne autyzmu według współczesnej klasyfikacji DSM- $V$ :

Stałe deficyty w zakresie komunikacji i interakcjach społecznych.

Ograniczone, powtarzalne wzorce zachowania i zainteresowań.

Symptomy są obecne już we wczesnym dzieciństwie.

Symptomy znacząco upośledzają codzienne funkcjonowanie ${ }^{18}$.

Warto zaznaczyć, że w 1962 r. amerykański psychiatra G. E. Vaillant wyróżniła aż 17 wspólnych cech W.H. z charakterystyką dzieci przedstawioną przez L. Kannera w 1943 r. $^{19}$

Prawdopodobnie dzieckiem z zaburzeniem ze spektrum autyzmu był też bardziej znany „dziki” Wiktor z Aveyron, znaleziony w 1800 r., gdy miał ok. 12 lat. Został opisany przez francuskiego lekarza i pedagoga Jeana Marca Itarda. Początkowo sądzono, że dramatyczny poziom funkcjonowania chłopca jest wynikiem braku socjalizacji i spodziewano się szybkich postępów w jego rozwoju, jednak mimo wielkich umiejętności, wiedzy i intuicji pedagogicznej młodego lekarza (miał zaledwie 26 lat, gdy powierzono jego opiece odnalezione dziecko), J. Itard nie zdołał osiągnąć przewidywanych rezultatów ${ }^{20}$.

Wiktor z Aveyron nie byt po prostu dzieckiem pozbawionym wychowania $i$ zycia społecznego, co ujawniło się $w$ jego ograniczonych zdolnościach adaptacji, jakby to ujęli

\footnotetext{
${ }^{16}$ Cyt. za: A. i F. Brauner, op. cit., s. 66.

17 Ibidem, s. 73.

18 J. Morrison, op. cit., s. 43.

19 T. Gałkowski, op. cit., s. 17.

${ }^{20}$ A. i F. Brauner, op. cit., s. 95.
} 
uczniowie Rousseau, lecz byt istota głęboko zaburzona, jeśli chodzi o życie psychiczne - uzasadniają niepowodzenie pedagoga A. i F. Braunerowie ${ }^{21}$.

Z początkiem XIX stulecia medycy dokonali jeszcze kilku podobnych opisów zaburzeń u dzieci. W 1803 r. angielski lekarz J. Haslam utrwalił przypadek chłopca w wieku 9 lat, który przejawiał zachowanie „zdecydowanie maniakalne” i był bardzo agresywny. Choć jego poziom intelektualny wydawał się umiarkowany, był świadomy swojego stanu: Bóg nie stworzyt mnie takiego jak inne dzieci - mówi²2. Wydaje się, że w tym wypadku J. Haslam mógł mieć do czynienia z jednostką określaną niegdyś jako zaburzenie hiperkinetyczne z towarzyszacym upośledzeniem umystowym i ruchami stereotypowymi (F84.4 w ICD-10), które to zaburzenie przypomina nakładanie się ADHD i niepełnosprawności intelektualnej ${ }^{23}$ według dzisiejszych kryteriów DSM- $\mathrm{V}^{24}$.

Pod koniec życia J. Itard, po przebadaniu w 1838 r. pewnego chłopca - Adriana H. - polecił jego rodzicom pomoc młodego i energicznego Edwarda Séguina - jednego z najwybitniejszych pedagogów francuskich ${ }^{25}$. W liście do ojca dziecka E. Séguin pisze:

Ciało wstrzasane jest bezustannymi ruchami konwulsyjnymi. Adrian nie mówit. Żąając jakiejś rzeczy od Adriana nie uzyskuje się prawie niczego, nie wykonuje on nigdy dwóch kolejnych poleceń [...] Inteligencję miat już dobrze rozwinięta, lecz nie przejawiat jej we właściwy sposób. Podsumowując można stwierdzić, że umie wykonywać różne czynności, umie myśleć i mówić, lecz pod warunkiem, iż ktoś inny zamiast niego chce to wszystko ${ }^{26}$.

Pozostawiona przez pedagoga charakterystyka nie pozwala wprawdzie orzec $\mathrm{z}$ całą pewnością, że Adrian był dzieckiem z autyzmem, ale niewątpliwie nie chodzi tu o proste braki inteligencji - jak zaznaczają A. i F. Brauner - entuzjaści E. Séguina ${ }^{27}$.

Po emigracji do USA i uzyskaniu doktoratu z medycyny E. Séguin dokonał szczegółowego opisu przypadku Emmy N., w którym można odnaleźć wszystkie charakterystyczne dla autyzmu cechy ${ }^{28}$. Charakterystyka ta ukazała się w pracy $O$ idiotyzmie, wydanej w połowie XIX w. Warto zaznaczyć, że u E. Séguina słowo idiota ma swoje oryginalne znaczenie - idios $\mathrm{w}$ języku greckim oznacza stać z boku, być izolowanym, wyróżniajacym się ${ }^{29}$.

Prace badawcze i działalność terapeutyczna J. Haslama, J. Itarda i E. Séguina w XIX w. świadczą o wzrastającym zainteresowaniu nauki zaburzeniami rozwoju u dzieci. Były to

\footnotetext{
21 Ibidem, s. 94.

22 Ibidem, s. 84-85.

23 T. Pietras, A. Witusik, op. cit., s. 19.

24 J. Morrison, op. cit., s. 34,49.

${ }^{25}$ A. i F. Brauner, op. cit., s. 108.

${ }^{26}$ Ibidem, s. 108-109.

27 Ibidem.

28 Ibidem, s. 111-118.

${ }^{29}$ Ibidem, s. 110.
} 
jednak tylko początki przemian w tej dziedzinie. Wypędzanie duchów i zdejmowanie uroków wciąż stanowiło częstszą praktykę, niż próby działań podejmowane przez lekarzy i pedagogów.

Okazuje się też, że w tamtych czasach, nawet trybunały sądowe były skłonne przyjąć, że rodzice, którzy doprowadzili do śmierci dziecka w toku takich praktyk, działali w dobrej intencji i uniewinniały ich od zarzutu dzieciobójstwa ${ }^{30}$. Jedno z takich orzeczeń sądowych, pochodzące z 1826 r., utrwalił T. C. Croker:

Oskarżona wyjaśniła, że to nie ona zabiła dziecko, lecz jego babka. Ustalono, że dziecko mając cztery lata, jeszcze nie chodziło ani nie mówiło. Zgodnie z otrzymanymi radami $i$ na polecenie babki podczas kolejnych trzech dni było ono zanurzane $w$ rzece. Trzecie zanurzenie zbyt przedtużajace się okazało się fatalne w skutkach ${ }^{31}$.

Intencją ekstremalnie radykalnych działań było zwykle wypędzenie z dziecka demona, ale przywołany wyrok sądowy dotyczy sprawy bardziej skomplikowanej - brali w niej bowiem udział „Good People” - tajemniczy lud czarowników i wróżek, który miał zamieszkiwać Irlandię. Według podań, wróżki z tego ludu nie potrafiły karmić swoich dzieci, dlatego zdarzało się, że przychodziły do mieszkań ludzkich i - korzystając z odpowiedniego momentu - zostawiały swoje dzieci w kołyskach, zabierając jednocześnie te, które było w niej uprzednio. Dzięki zaczarowaniu dziecko wróżki przybierało identyczny wygląd jak to ,podmienione” - tak, iż matka na początku nie zauważała zamiany. Dzieci te zachowywały się jednak w sposób niecodzienny i z reguły nie mówiły, żeby się nie zdradzić ${ }^{32}$.

W baśniach znano sposoby zdemaskowania odmieńca, nieco trudniej było z odzyskaniem swojego dziecka. Podmienione dziecko należało zaskoczyć bądź wystraszyć, tak aby spowodować wybuch śmiechu lub nagłą wypowiedź. Po zdemaskowaniu potwora należało go torturować, wrzucić do rzeki, zostawić na mrozie, wsadzić do pieca albo spalić w ognisku. Mądrzy ludzie znali metody niezawodne. W baśniach istniała zawsze szansa, że w ostatniej chwili pojawią się „Good People” i oddadzą dziecko prawdziwe ${ }^{33}$.

Jak sądzą A. i F. Brauner ${ }^{34}$, w tego typu relacjach można odnaleźć elementy opisów zaburzeń u dzieci charakterystycznych dla spektrum autyzmu.

Moment zamiany dziecka przypomina regres rozwojowy jakiego doświadcza ok. 25-30\% dzieci z autyzmem w ciągu pierwszych trzech lat życia. Zachodzi nagle lub stopniowo, nakładając się na istniejące wcześniej subtelne opóźnienia rozwojowe lub atypowy przebieg rozwoju. Wyraźnie obserwowalna zmiana w zachowaniu dotyczy rozwoju

\footnotetext{
${ }^{30}$ A. i F. Brauner, op. cit., s. 30.

31 T. C. Croker, Fairy Legendsof the South of Ireland, 1826, cyt. za: A. i F. Brauner, op. cit., s. 28.

32 Ibidem, s. 20.

33 Ibidem, s. 28.

34 Ibidem, s. 21-22.
} 
mowy, gestykulacji, zachowań społecznych oraz zmian w sposobie zabawy dziecka. Nieznane są obecnie mechanizmy leżące u podłoża tego zjawiska ${ }^{35}$.

Wywoływane magicznymi metodami wybuchy śmiechu lub wypowiedzi dzieci przypominają specyficzne dla dzieci z autyzmem zaburzone formy komunikacji - odtwórcze, nieraz nieskładne gramatycznie i nieadekwatne do sytuacji, co zauważyli w swoich obserwacjach już L. Kanner $^{36}$ i H. Asperger ${ }^{37}$.

Tajemnicze dziecko fada $^{38}$ można odnaleźć w baśniach skandynawskich, staroangielskich, szkockich, niemieckich, francuskich, a także słowiańskich. Odnajdując podobny opis w jednej z chińskich baśni, badacze zagadnienia stwierdzają, że fenomen ten nie jest czymś charakterystycznym tylko dla europejskiego kręgu kultury ${ }^{39}$.

Źródła takie stanowiły w owym czasie wiedzę powszechną. Zwraca uwagę fakt, że w relacjach tych rodzice przyjmują wszelkie szarlatańskie porady zupełnie bezkrytycznie i skłonni są bez wahania podjąć najbardziej radykalne kroki ${ }^{40}$. Badacze historii autyzmu odnaleźli oficjalne dokumenty ${ }^{41}$ świadczące o tym, że jeszcze w $1851 \mathrm{r}$. w Irlandii, zdarzały się przypadki umyślnego powodowania śmierci dziecka przez jego rodziców, wywołane okrucieństwem znachorów i szarlatanów, trudniących się zdejmowaniem uroków.

I tak działo się do końca XIX w., kiedy to nauka zaczyna opisywać i nazywać swoim językiem niezwykłe dziecięce zaburzenia rozwoju. Minie jeszcze wiele czasu nim autyzm zostanie w ogóle wyodrębniony. Nie znaczy to oczywiście, że nie istnieje. Nie umknął też uwadze literatury XIX w. William Wordsworth, Walter Scott, Joseph Conrad - to brytyjscy pisarze, którzy pierwsi wprowadzili do literatury światowej postacie zaburzonych dzieci ${ }^{42}$.

We wszystkich czasach pisarze wyprzedzali naukę, starając się wyobrazić sobie to, czego nauka jeszcze nie opanowała. Pod pewnym względem twórcy wyprzedzili naukę zdecydowanie, zauważając cierpienie i wielokrotne rozpaczliwy wysiłek rodziny tych dzieci:

Ewa skoncentrowała wszystkie sity, by wydobyć dziecko z jego niebytu ${ }^{43}$.

${ }_{35}$ M. Skórczyńska, Wczesne diagnozowanie autyzmu - perspektywy i dylematy, w:, Autyzm - na granicy zrozumienia, Winczura B. (red.), Kraków 2009.

36 T. Gałkowski, op. cit., s. 13.

${ }^{37}$ M. Szydziak, Ewolucja poglądów na przyczyny autyzmu, w: D. Marzec, A. Banasiak (red.), Dziecko z autyzmem: rozważania teoretyczne, doniesienia z badań, Częstochowa 2005.

${ }^{38}$ Fada - oznacza wyposażenie kogoś we własności magiczne, etymologicznie wywodzi się z „fata” pochodzącego od „fatum” (przeznaczenie), nie mając jednocześnie nic wspólnego z łacińskim „fatuus” - głupi.

39 A. i F. Brauner, op. cit., s. 35.

40 Ibidem, s. 28.

${ }^{41}$ Oficjalny raport Sir Wiliama Wilde'a za rok 1851, cytowany w książce Kevina Danahera The year in Ireland.

42 A. i F. Brauner, op. cit., s. 135.

${ }^{43}$ Loyré d'Arbouville, Doktor Barnaba, 1847, cyt. za: A. i F. Brauner, op. cit., s. 152. 


\section{Droga do odkrycia Kannera}

Pionierski artykuł L. Kannera Zaburzenia autystyczne kontaktu afektywnego ukazał się w 1943 r. w kontekście rosnącego w XX w. zainteresowania nauki zaburzeniami rozwoju u dzieci.

Włoski lekarz Sante de Sanctis w 1905 r. opisał chorobę, którą nazwał „najwcześniejsza demencja" - określenie to pochodziło od terminu dementia praecox zaproponowanego natomiast przez niemieckiego psychiatrę Emila Kraepelina. W 1911 r. dementia praecox została zastąpiona pojęciem schizofrenii, wprowadzonym do psychiatrii przez Szwajcara Eugena Bleulera ${ }^{44}$.

Wiedeński pedagog terapeuta Teodor Heller w 1908 r. opisał bardzo szczegółowo 6 przypadków „bardzo osobliwej demencji”, znacznie odróżniających się od zwykłego obniżenia inteligencji, charakteryzujących się natomiast objawami zbliżonymi do objawów autyzmu i - co istotne - pojawiającymi się nagle pomiędzy 2 a 3 rokiem życia, po okresie zupełnie prawidłowego rozwoju. Niemiecki psychiatra Wilhelm Weygandt określił przypadki opisane przez Hellera jako dementia infantilis, ostatecznie przyjęto nazwę schizofrenia dziecięca.

W 1931 r. badacz o nazwisku Corbert przeprowadził pierwszą biopsję u czwórki dzieci z objawami tego zaburzenia, znajdując oznaki organicznych uszkodzeń w ośrodkowym układzie nerwowym. Praca ta nie wzbudziła jednak szerszego zainteresowania - dla psychiatrów schizofrenia była z natury zaburzeniem funkcjonalnym, bez żadnych czynników o organicznej etiologii ${ }^{45}$.

W książce profesora Heinricha Hanselmanna z uniwersytetu w Zurychu Wprowadzenie do pedagogiki leczniczej wydanej w 1935 r. pojawia się pierwszy rzetelny, naukowy opis dzieci w normie intelektualnej uznawanych za psychotyczne. Szwajcarski pedagog pisze o dzieciach „pozbawionych uczuciowości” (gefühlsstumpf) lub inaczej „idiotach w sferze uczuć" (gefühlsblöd), choć opisy te trudno utożsamiać z zaburzeniami ze spektrum autyzmu - wbrew terminologicznym pozorom odbiegają one znacznie od charakterystyk przedstawionych później przez L. Kannera i H. Aspergera: Uważa się ich za egoistów bez ograniczeń, nie posiadających serca ani uczuć. Różnia się oni od wszystkiego $w$ naszym świecie. [...] Dla tych dzieci nie ma nic świętego, nie obawiaja się niczego, ponieważ niczego nie kochaja, a to, czym się interesuja, to jest ich własne Ja. [...] Pod względem uczuciowym sa puści, nie sa przywiązani ani do żadnych przedmiotów ani tė̇ do osób $b^{46}$.

Zaznaczanie powyższych dociekań badawczych pozwala zilustrować klimat naukowy, w jakim pojawiły się dwie kluczowe dla historii autyzmu prace, powstałe po dwóch stronach frontu światowego konfliktu, w tych krajach, gdzie głód $i$ wojna nie stanowity dominującego nieszczęśsia ${ }^{47}$.

\footnotetext{
44 A. i F. Brauner, op. cit., s. 192.

45 Ibidem, s. 193.

${ }^{46}$ Cyt. za: A. i F. Brauner, op. cit., s. 194.

${ }^{47}$ Ibidem, s. 198.
} 
Dwadzieścia lat po emigracji do USA, w roku 1943 r., pediatra pochodzenia austriackiego Leo Kanner posłużył się wyrazem autyzm w swoim artykule przy opisie 11 przypadków. Rok później podobny opis przedstawił w Niemczech inny Austriak Hans Asperger w artykule Psychopaci autystyczni wieku dziecięcego. Ich koncepcje nie pokrywały się zupełnie, a opisane przypadki różniły się stopniem zaburzenia. Dalsze wydarzenia pozostawiły Aspergera w cieniu i minęło sporo czasu zanim termin spektrum autystyczne połączył te opisy ${ }^{48}$.

Obie prace były kazuistyczne i bardzo szczegółowe, lecz - jak pisze Tadeusz Gałkowski - zawierały dużo subiektywnych i nieprecyzyjnych określeń dotyczących obserwowanych zachowań ${ }^{49}$. Swoje obserwacje L. Kanner rozpoczął w 1938 r. w Klinice Psychiatrycznej Uniwersytetu Johnsona Hopkinsa. Po pięciu latach opublikował swoje spostrzeżenia w czasopiśmie „Nervous Child" ${ }^{50}$. Praca pojawiła się ponownie w międzynarodowym magazynie „Acta Paedopsychiatrica" ${ }^{51}$. Określenie wrodzonego zaburzenia autystycznego kontaktu afektywnego weszło na stałe do terminologii fachowej ${ }^{52}$.

Mimo iż koncepcje dotyczące istoty i etiologii autyzmu przeszły od czasu opisu L. Kannera znaczną ewolucję, jego praca dała początek systematycznym badaniom nad autyzmem i jest przytaczana we wszystkich niemal publikacjach na ten temat ${ }^{53}$.

\section{Opis Kannera i jego znaczenie}

Wśród 11 dzieci opisanych przez L. Kannera było 8 chłopców i 3 dziewczynki, żadne z nich nie miało jeszcze ukończonych 11 lat. Każdy opisany przypadek przedstawiał inny obraz indywidualny, lecz badacz dostrzegł wspólne dla nich komponenty tworzące zespół zaburzeń: Od 1938 roku uwage nasza zwróciła pewna liczba dzieci, których zachowanie odbiega wyraźnie od pozostatych $w$ takim stopniu, że każdy przypadek zastuguje na to (i mam nadzieję, że to się stanie), by zająć się nim szczegółowiej wraz ze wszystkimi fascynujacymi nas jego cechami ${ }^{54}$.

Nie jest celem tego artykułu streszczanie opisów wszystkich 11 przypadków (można je odnaleźć w książce A. i F Brauner, s. 196-212). Istotne jest w tym miejscu przywołanie tych elementów raportu L. Kannera, które stały się punktem odniesienia dla tworzonych koncepcji etiologii autyzmu oraz źródłem licznych kontrowersji.

\footnotetext{
48 Ibidem, s. 196.

49 T. Gałkowski, op. cit., s. 14.

50 „Nervous Child” 1943, vol 2 nr 3.

51 „Acta Pedopsychiatrica” 1968, vol. 35, nr 4-8, s. 198-136.

52 T. Gałkowski, op. cit., s. 14.

53 A. i F. Brauner, op. cit., s. 197.

${ }^{54}$ L. Kanner 1943, cyt. za: A. i F. Brauner, op. cit., s. 198.
} 
W pierwszej kolejności należy zaznaczyć, że już w swoim pierwszym opisie L. Kanner wyróżnił charakterystyczne dla wszystkich przypadków objawy behawioralne mieszczące się w dwóch cechach osiowych. Były to:

autystyczna samotność (autistic aloneness) - nieumiejętność nawiązywania kontaktów z ludźmi i zamiłowanie do przedmiotów, przejawiające się brakiem kontaktów emocjonalnych z najbliższymi osobami oraz zaburzeniem rozwoju mowy i jej nieadekwatność do sytuacji;

pragnienie niezmienności (desire of sameness) - stereotypie spowodowane obsesyjnym lękiem ujawniające się nadmierną koncentracją na przedmiotach i manipulowaniem nimi oraz wielokrotnie powtarzanymi stereotypowymi ruchami i zachowaniami ${ }^{55}$.

Obecne kryteria diagnostyczne również wyróżniają dwa objawy osiowe. Są to deficyty społeczno-komunikacyjne oraz uporczywe zainteresowania i powtarzalne zachowania $^{56}$. Co do treści są one tożsame $\mathrm{z}$ charakterystyką przedstawioną przez austriackiego pediatrę, dlatego można zgodzić się z poglądem T. Gałkowskiego, że lista objawów podana przez L. Kannera stała się klasycznym zestawem cech autyzmu dziecięcego ${ }^{57}$.

Głównym objawem u obserwowanych dzieci była zdaniem L. Kannera: niezdolność do nawiązywania kontaktów w zwykty sposób z osobami, w codziennych sytuacjach, występujaca już od najwcześniejszego dzieciństwa. Dzieci te były - jak mieli mówić ich rodzice - samowystarczalne oraz najszczęśliwsze wówczas, gdy je zostawiano same i zachowujace się tak, jakby wokót nich nie było ludzi $i^{58}$.

Troje z dzieci nie posługiwało się mową. U 8 dzieci mowa nie spełniała funkcji komunikacyjnej - umiały one nazywać przedmioty i zapamiętywać trudne określenia i zwroty, choć nie były w stanie budować wypowiedzi, które stanowiłyby przekaz sensownych myśli, pragnień czy pytańn ${ }^{59}$.

Kanner wyraźnie zaznaczał, że dzieci te były dość sprawne intelektualnie, choć znaczące ograniczenia w nawiązaniu trwałego kontaktu uniemożliwiały zbadanie ich standardowymi testami inteligencji ${ }^{60}$. Ponadto ,odznaczały się wszystkie inteligentną fizjonomią".

Pediatra, zaburzenia u opisywanych dzieci, określił jako „wrodzone”, choć sam T. Gałkowski twierdzi, że badacz posłużył się tym określeniem nie będąc jeszcze w petni przekonany o ich rzeczywistym pochodzeniu ${ }^{61}$.

${ }^{55}$ L. Bobkowicz-Lewartowska, op. cit., s. 12.

${ }^{56} \mathrm{~W}$ literaturze wydanej przed ukazaniem się najnowszej wersji klasyfikacji $D S M-V$ podaje się nie dwa, lecz trzy objawy osiowe autyzmu: (1) jakościowe zaburzenia interakcji społecznych, (2) jakościowe zaburzenia komunikacji, (3) ograniczone i powtarzające się stereotypowe formy aktywności [zob. T. Pietras, A. Witusik, op. cit., s. 19]. $D S M-V$ wprowadziło połączenie dwóch grup objawów z dotychczasowej triady diagnostycznej w jedną domenę - deficyty społeczno-komunikacyjne. Zmiany te - istotne z punktu widzenia diagnostyki - nie wpływają na aktualność prezentowanych w niniejszym artykule zagadnień.

\footnotetext{
57 T. Gałkowski, op. cit., s. 14.

${ }^{58}$ Ibidem.

${ }^{59}$ Ibidem.

${ }^{60}$ Ibidem, s. 15.

${ }^{61}$ Ibidem, s. 14.
} 
Opisane przez L. Kannera dzieci pochodziły z rodzin inteligenckich o wysokim statusie socjokulturowym - wśród krewnych i dziadków tych dzieci przeważali lekarze, naukowcy, pisarze, dziennikarze i twórcy z zakresu sztuk pięknych - pisze T. Gałkowski: Praca zabierała im dużo czasu i nie stwarzali dzieciom $w$ domu rzeczywiście ciepłej atmosfery, niezbędnej dla normalnego rozwoju emocjonalnego. Dzieci wyrastały więc w środowisku chłodnym uczuciowo [podkr. K.O.], gdzie większe znaczenie przywiąywano do atrakcyjnych wartości zwiazanych ze sztuka, nauka, sprawami zawodowymi aniżeli do kontaktów międzyludzkich ${ }^{62}$.

L. Kanner odróżnił w swoim badaniu opisane przypadki od schizofrenii dziecięcej. Schizofrenię dziecięcą poprzedzają przynajmniej dwa lata prawidłowego rozwoju, tymczasem opisane przez Kannera dzieci już od pierwszych miesięcy życia ujawniały rozwojowe anomalie ${ }^{63}$.

Praca L. Kannera spotkała się z powszechnym uznaniem, jego badania kontynuowano i rozszerzano. W $1971 \mathrm{r}$. w Waszyngtonie rozpoczęto wydawanie kwartalnika „Jurnal of Autism and Childhood Schizophrenia" dedykowany wyłacznie problematyce psychoz dziecięcych i autyzmu ${ }^{64}$.

Po opisie L. Kannera uwagę badaczy zwróciły dawniej opisane przypadki - pod wieloma względami bardzo podobne. Należały do nich prace m. in. J. Haslama z 1809 r., Meyera i Richardsa z 1921, L. Desperta z 1938 r., czy Witmera z 1920 r. ${ }^{65}$

L. Kanner dużo uwagi poświęcił rodzicom opisywanych dzieci, co sprawiło, że psychoanalitycy ustalili związek pomiędzy cechami rodziców a autyzmem. Poglądy te przyjęli w zasadzie wszyscy profesjonaliści. Jak podkreśla Lucyna Bobkowicz-Lewartowska psychoanalitycznej indoktrynacji uległy też całe pokolenia rodziców, wierząc, że są sprawcami zaburzenia swojego dziecka ${ }^{66}$. Największa katastrofa w badaniach nad autyzmem nastąpiła tuż po tym, jak nauka zdobyła się wreszcie na wysiłek jednoznacznego zdefiniowania go.

Nie była to jednak - jak się wciąż często uważa - opinia L. Kannera ${ }^{67}$. Jako pediatra łączył on braki w zdolnościach nawiązywania kontaktu afektywnego z funkcjonowaniem neurobiologicznym: Należy zatem przyjąć, że dzieci przyszły na świat z pewna wrodzona niezdolnościa [podkr. K.O.] uniemożliwiająca im normalne nawiązywanie kontaktu afektywnego z kimś drugim. Jest to niezdolność uwarunkowana możliwościami biologicznymi podobnie jak u innych dzieci, które rodza się z podobnym brakiem fizycznym lub intelektualnym... - pisze Leo Kanner w swoim artykule z roku $1943^{68}$.

62 Ibidem, s. 15.

63 Ibidem, s. 17.

${ }^{64}$ Ibidem.

65 Ibidem, s. 17-18.

${ }^{66}$ L. Bobkowicz-Lewartowska, op. cit., s. 20.

${ }^{67}$ M. Talarowska i in., Badanie psychologiczne $w$ autyzmie, w: T. Pietras, A. Witusik, P. Gałecki (red.), Autyzm..., s. 101.

${ }^{68}$ L. Kanner [cyt. za:] A. i F. Brauner, op. cit., s. 218. 
Opis zachowań rodziców, których L. Kanner przedstawił jako „,intelektualistów, zimnych i sztywnych", pozwolił badaczom z nurtu psychoanalitycznego na przypisanie „winy” wystąpienia zaburzenia rozwoju u dziecka jego rodzicom, wraz ze wszystkimi tego konsekwencjami ${ }^{69}$. Chciałbym tu oświadczyć, że was uniewinniam jako rodziców. Bytem cytowany w sposób falszywy wiele razy [podkr. K.O.]. Postużytem się stowem, które nie jest wieloznaczne - ,, wrodzony”, lecz ze względu na to, że podatem charakterystykę osobową rodziców bytem źle interpretowany, jakbym miat rzekomo powiedzieć: „Wszystko to jest wina rodziców” [podkr. K.O.]. Ci spośród was, którzy przyszli wraz ze swoimi dziećmi mnie zobaczyć, wiedza dobrze, że nigdy czegoś takiego nie mówitem. $W$ istocie rzeczy starałem się ulzyć zaniepokojonym rodzicom, których takie spekulacje napawały lękiem - powiedział Leo Kanner podczas I Kongresu Krajowego Stowarzyszenia dla Dzieci Autystycznych w San Francisco 17 lipca 1969 r. ${ }^{70}$

\section{Psychoanalityczne teorie dotyczące przyczyn autyzmu}

Sam L. Kanner zdawał sobie sprawę, że słowo autyzm zostało niefortunnie dobrane, o czym pisze w swoim artykule Infantile autism and the schizophrenias, lecz nie znalazł lepszego określenia ${ }^{71}$. Termin został zaczerpnięty od Eugena Bleulera, który posłużył się określeniem autyzm już w 1911 r. do opisu jednego z głównych objawów schizofrenii specyficznemu odcięciu od otaczającego świata ${ }^{72}$. Użycie tego terminu okazało się niefortunne z kilku powodów. Po pierwsze, powodowało kojarzenie zespołu opisanego przez L. Kannera z formą psychopatii schizoidalnej, co skutkowało myleniem informacji na temat tych dwóch, odmiennych zaburzeń. Po drugie, termin autyzm funkcjonował w różnych ujęciach teoretycznych. Przykładowo Mahler pierwsze stadium rozwoju psychicznego nazywał fazą autyzmu. W teorii Piageta autyzm stanowił pierwotną fazę rozwoju. Termin używany jest też w wyrażeniach przymiotnikowych, takich jak autystyczne zachowanie czy autystyczna reakcja ${ }^{73}$.

Prawdopodobnie pod wpływem pracy L. Kannera, zawierającej charakterystyki rodziców dzieci z autyzmem, pierwsze poszukiwania odpowiedzi na pytanie o przyczyny zaburzenia były podejmowane w nurcie psychoanalitycznym. Warto przytoczyć w tym miejscu stworzone przez M. K. DeMayer tabelaryczne zestawienie poglądów tych autorów, którzy po doniesieniu L. Kannera poszukiwali czynników sprawczych autyzmu w tym paradygmacie naukowym (tabela 1 ).

${ }^{69}$ A. i F. Brauner, op. cit., s. 218.

${ }^{70}$ L. Kanner [cyt. za:] A. i F. Brauner, op. cit., s. 218.

${ }^{71}$ A. i F. Brauner, op. cit., s. 197.

${ }^{72}$ B. Winczura, Zaburzenia ze spektrum autystycznego: różnicowanie diagnostyczne, w: Pedagogika specjalna - koncepcje i rzeczywistość, T. 6, Wyzwania współczesnej pedagogiki specjalnej-praktyka edukacyjna i rewalidacyjna, Żółkowska T., Ostapiuk B., Wlazło M. (red.), Szczecin 2000, s. 61.

73 Ibidem, s. 61-62. 
Tabela 1. Teorie przypisujące powstanie autyzmu dziecięcego czynnikom psychogennym

\begin{tabular}{|l|l|}
\hline Bettelheim (1958) & Odrzucenie i gniew ze strony rodziców. \\
\hline Des Lauries (1962) & $\begin{array}{l}\text { Teoria psychanalityczna dotycząca „ego”. Niezdolność do nawiązywania kontaktu } \\
\text { z rzeczywistością. }\end{array}$ \\
\hline Pavensted (1955) & Psychotyczna więź matki z dzieckiem. \\
\hline Knight (1963) & $\begin{array}{l}\text { Niemożność ustalenia u dziecka prymatu oralnego, która doprowadza do tego, że } \\
\text { rozwój funkcji poznawczych przechodzi z ,ego” eksteroceptywnego do interoceptyw- } \\
\text { nego. }\end{array}$ \\
\hline Sznurek (1956) & $\begin{array}{l}\text { Zaburzenie osobowości u obojga rodziców. Reakcje dziecka stanowią spotęgowanie } \\
\text { ich zaburzeń. }\end{array}$ \\
\hline Clerk (1961) & $\begin{array}{l}\text { Trudności w porozumiewaniu się matki z dzieckiem. U dziecka występuje nasilony } \\
\text { lęk spowodowany agresywnym postępowaniem matki. }\end{array}$ \\
\hline Ferster (1961) & Rodzice wzmacniają występowanie patologicznych objawów u dziecka. \\
\hline
\end{tabular}

Źródło: DeMayer, 1977, za: T. Gałkowski, op. cit., s. 29.

M. K. DeMayer dokonał również zestawienia badaczy, których poglądy dotyczące przyczyn autyzmu uwzględniają zarówno czynniki funkcjonalne, jak i organiczne (tabela 2).

Tabela 2. Teorie przypisujące powstanie autyzmu dziecięcego współdziałaniu czynników organicznych i psychogennych

\begin{tabular}{|l|l|}
\hline Anthony (1958) & $\begin{array}{l}\text { Środowisko i czynniki organiczne stają się powodem zaburzeń psychotycz- } \\
\text { nych u dziecka. }\end{array}$ \\
\hline Eisenberg i Kanner (1956) & Współdziałanie przyczyn wrodzonych i doświadczeń osobistych. \\
\hline Garcia i Sarvis (1964) & $\begin{array}{l}\text { Reakcje patologiczne pojawiają się między 6 a } 18 \text { miesiącem życia jako } \\
\text { wynik działania różnorodnych bodźców psychologicznych i fizycznych. }\end{array}$ \\
\hline Goldfab (1961) & $\begin{array}{l}\text { Opisuje przypadki „organiczne” i nieorganiczne. Dzieci reprezentujące } \\
\text { pierwszy typ posiadają bardziej zrównoważone rodziny. }\end{array}$ \\
\hline Rank (1955) & Czynniki dziedziczne i biologiczne oraz posiadanie „niby” matek. \\
\hline Mahler (1955) & $\begin{array}{l}\text { Niemowlę posiada konstytucjonalny defekt „,ego”, co może stwarzać „,błędne } \\
\text { koło” w patologicznej więzi matki z dzieckiem. }\end{array}$ \\
\hline Bene (1958) & $\begin{array}{l}\text { Matki dzieci z nasilonymi zaburzeniami autystycznymi są mniej zdolne do } \\
\text { nawiązywania kontaktów społecznych i więzi emocjonalnej, aniżeli matki } \\
\text { dzieci z lżej nasilonymi zaburzeniami. }\end{array}$ \\
\hline
\end{tabular}

Źródło: DeMayer, 1977, za: T. Gałkowski, op. cit., s. 30.

W latach 50. i $60 . \mathrm{XX}$ w. budowano też pierwsze teorie o organicznym podłożu autyzmu, zwracając m.in. uwagę na czynniki, takie jak: uszkodzenie tworu siatkowatego (Rimland, 1960), nadmiar tlenu w organizmie (hiperoxia), upośledzenie w zakresie korowego hamowania i pobudzania - zgodnie z koncepcją Pawłowa (Macmillan, 1961), czy trudności w regulacji czasu reakcji na poziomie spostrzeżeniowo-ruchowym, wynikające 
z czynników neurologicznych (Fish, 1960). Dominującym nurtem w poszukiwaniach odpowiedzi na przyczyny autyzmu pozostał jednak nurt psychodynamiczny, mając tym samym ogromny wpływ na kształtowanie postaw i poglądów kolejnych badaczy, specjalistów podejmujących oddziaływania terapeutyczne oraz samych rodzin osób z autyzmem ${ }^{74}$.

Jednym z najbardziej wpływowych badaczy postulujących wyjaśnianie przyczyn autyzmu czynnikami psychogennymi i środowiskowymi był Bruno Bettelheim ${ }^{75}$. Podobnie jak wielu innych autorów, przypisywał on decydującą rolę w etiologii zaburzenia postawie wychowawczej rodziców, którzy stanowią istotny czynnik patogenny. Pogląd taki miał bardzo istotne konsekwencje dla praktyki terapeutycznej.

B. Bettelheim ujmował autyzm jako reakcję dziecka na wrogie otoczenie, przynoszące mu cierpienie. Dziecko nie przejawia zaufania w stosunku do otaczającej rzeczywistości, przez co tłumi wszelki napęd do wchodzenia w interakcje $\mathrm{z}$ otoczeniem, unikając w ten sposób zagrażających mu urazów psychicznych. Brak zaufania do rzeczywistości powoduje wycofanie się z niej, mimo że mogłoby znaleźć w niej zaspokojenie swoich potrzeb. Autyzm staje się więc ostatnią fortecą dającą schronienie przed cierpieniem ${ }^{76}$.

Psychiatra ten wykorzystał w swej teorii koncepcje krytycznych momentów w rozwoju dziecka. Jeśli w którymś z tych krytycznych okresów dziecko odbierze informacje, że świat jest niebezpieczny, nie zaspokaja jego potrzeb i dostarcza jedynie frustracji, może „ulec przekonaniu”, że świat ten nie jest wart zaufania, nie można na niego liczyć i trzeba go unikać. Ten świat niewrażliwy nie musi oznaczać braków w opiece niezbędnej dla zdrowia fizycznego, lecz świat niewrażliwy na potrzeby psychiczne, na naturalną potrzebę nawiązywania kontaktów psychicznych.

Metafora pustej fortecy - choć spotkała się z krytyką ze strony autorów skłonnych poszukiwać przyczyn autyzmu w czynnikach organicznych - okazała się fascynującą dla wielu badaczy i znalazła licznych zwolenników ${ }^{77}$.

B. Bettelheim i jego zwolennicy przedstawiali dość specyficzny rodzaj podejścia psychoanalitycznego, wykorzystując koncepcje wywodzące się z filozofii, socjologii i innych nauk humanistycznych. Wyjaśniając przyczyny zachowania dziecka z autyzmem przyjętym paradygmatem, Bettelheim pisze: Aby działać jako istota ludzka trzeba wpierw nauczyć się jak należy zorganizować swoje własne życie $w$ zależności od czasu, przestrzeni i czynników przyczynowych. Te trzy kategorie umystowe nie maja wyłacznie charakteru metafizycznego, lecz ujawniaja się także w rzeczywistości historycznej i genetycznej. Orientacja w czasie i przestrzeni wyprzedza poczucie przyczynowości. [...] Lecz w świecie, $w$ którym nie istnieje żadna przyczynowość, żadne przewidywanie, nie jest możliwy żaden projekt działania. Jeśli nie potrafimy przewidzieć rezultatów naszego działania, nie będziemy $w$ stanie kontrolować naszej przyszłości. Znaczenia nabieraja wtedy dwa rozwiąania: powstrzymanie się od działania, co umożliwia przynajmniej zaoszczędzenie

\footnotetext{
${ }^{74}$ T. Gałkowski, op. cit., s. 30-31.

75 Ibidem, s. 34.

${ }^{76}$ Ibidem, s. 21.

${ }^{77}$ Ibidem.
} 
energii i pozwala uniknać zawodu, lub wytworzenie świata urojonego, w którym możemy wyobrazić sobie, że kontrolujemy nasze losy ${ }^{78}$.

Budując swoją koncepcję wyjaśniania objawów autyzmu u dzieci, B. Bettelheim uciekał się do obserwacji poczynionych podczas swojego pobytu w obozach koncentracyjnych. Psychiatra został deportowany do Dachau w 1939 r., później został przeniesiony do Buchenwaldu ${ }^{79}$. Badacz był w tych miejscach światkiem patologicznych form reakcji więźniów na represje jakich doświadczali: prób samobójczych, objawów katatonii ${ }^{80}$, melancholijnej depresji i innych zachowań spotykanych w poważnej chorobie psychicznej zwanej schizofrenią. Powodem tych patologicznych zachowań - zróżnicowanych ze względu na odmienne cechy osobowościowe - było ,życie w sytuacji krańcowej”. Zdaniem B. Bettelheima: to co dla tych więźniów było rzeczywistościa zewnętrzna, w przypadku dzieci autystycznych stanowi rzeczywistość wewnętrzna ${ }^{81}$.

$\mathrm{Z}$ tych powodów B. Bettelheim postulował umieszczanie tych dzieci w specjalnych ośrodkach oraz poddanie rodziców psychoterapii ${ }^{82}$.

Oprócz B. Bettelheima wyjaśnienia przyczyn autyzmu na gruncie psychoanalizy poszukiwali też inni badacze. Melanie Klein w swojej teorii zaburzenia procesu separacji -indywidualizacji przedstawia zachowanie autystyczne jako adaptację schizoidalną - wynik nieprawidłowej i „zimnej” opieki opiekunów, w szczególności matki ${ }^{83}$. Margaret Mahler przedstawiła rozbudowaną teorię etiologii autyzmu jako efektu utraty lub wycofania kateksji z ludzkiego aspektu reprezentacji obiektu i zachowania relacji z nieożywionym i mechanicznym obiektem ${ }^{84}$. Francis Tustin upatrywała przyczyn autyzmu w przedwczesnej utracie symbiotycznego związku z matką. Natomiast Niko Tinbergen zakładał, że zachowania charakterystyczne dla autyzmu mogą pojawić się jako reakcja na silny lęk odczuwany przez dziecko w wyniku braku poczucia bezpieczeństwa w relacji $\mathrm{z}$ matką ${ }^{85}$.

${ }^{78}$ B. Bettelheim, La forteresse vide. L'autism infant ile at la naissance du Soi, Paryż, 1969, Gallimard, s. 83-83; za: T. Gałkowski, op. cit., s. 21.

79 T. Gałkowski, op. cit., s. 22.

${ }^{80}$ Katatonia - jedna z psychoz schizofrenicznych, charakteryzujących się silnym pobudzeniem psychoruchowym (podniecenie albo szał katatoniczny) lub spowolnieniem aż do całkowitego znieruchomienia (osłupienie lub stupor katatoniczny); stany te mogą przechodzić jeden w drugi (Słownik psychologii, red. Jerzy Siuta, s. 120, Wydawnictwo Zielona Sowa, Kraków 2005).

81 Ibidem, s. 22.

${ }^{82}$ L. Bobkowicz-Lewartowska, op. cit., s. 27.

${ }^{83}$ Ibidem.

84 Ibidem, s. 22.

${ }^{85}$ M. Talarowska i in., op. cit., s. 102. 


\section{Krytyka koncepcji o psychogennej etiologii autyzmu}

Teorie upatrujące przyczyn autyzmu w psychogennych czynnikach, nie znalazły żadnego oparcia w badaniach empirycznych ${ }^{86}$. Przyniosły jedynie niepotrzebne nieporozumienia i ogromne cierpienia zarówno dzieciom, jak i rodzicom dzieci autystycznych, którzy odegrali rolę kozła ofiarnego. Terapia oparta na założeniach psychodynamicznych okazała się całkowicie nieskuteczna ${ }^{87}$.

Jednym z pierwszych badaczy, który odważył się przełamać ten stereotyp był Carl Delacato. Jego koncepcja zakładała, że przyczyną niezwykłych zachowań dzieci autystycznych są uszkodzenia mózgu. Pisze: Dzieci nie były psychotyczne. Miały uszkodzenia mózgu i poważne problemy sensoryczne. [...] Dzieci te nie byly autystyczne z przyczyn psychologicznych, lecz zachowywały się w sposób sugerujacy podtoże neurologiczne ${ }^{88}$.

Jakkolwiek metoda terapeutyczna opracowana przez C. Delacato jest obecnie poddawana ostrej dyskusji, spostrzeżenia poczynione przez tego badacza miały duży wpływ na sposób rozumienia wielu zachowań dzieci z autyzmem.

Psychoanaliza poszła jednak jeszcze dalej, sugerując, że niewłaściwa interakcja podczas karmienia piersią wywołuje autyzm ${ }^{89}$.

W miarę upływu czasu, a zwłaszcza w Salem, diagnoza, że ktoś jest czarownica opierała się na coraz bardziej wymyślnych dowodach. Należało jedynie obejrzeć sutki. [...]

Chociaż używamy teraz dużo subtelniejszych określeń, czyż nie korzystamy z tych samych, strasznych koncepcji, żeby winić matki za pojawienie się wśród nas tych obcych nam istot?

Nie mogłem zgodzić się z teoria „oziębłości” $i$,,dawania piersi”. Prowadzity one w ślepa uliczkę. Zrobiono z tych kobiet kozty ofiarne ${ }^{90}$.

Komentując liczne koncepcje psychogennej etiologii autyzmu T. Gałkowski pisze:

Wydaje się, że tak beztroskie obciążanie rodziców odpowiedzialnościa [podkr. K.O.] za powstanie u dziecka jednej z najbardziej poważnych anomalii rozwojowych, jest postawa niesprzyjajaca dalszemu wychowaniu dziecka $w$ rodzinie $i$ samo $w$ sobie zawiera możliwość spowodowania $u$ nich silnych konfliktów emocjonalnych. Jest to sytuacja, w której próba wyjaśnienia przez specjalistę przyczyn schorzenia, może sama wywołać schorzenie (działania jatrogenne) ${ }^{91}$ - komentuje koncepcje B. Bettelheima T. Gałkowski.

A. Brauner, będący w zdecydowanej opozycji do poglądów B. Bettelheima, w swojej książce podsumowującej 20 lat jego doświadczenia w pracy usprawniającej z dziećmi z autyzmem, pisał: Po dwudziestu latach tej pracy próbuję obliczyć, ile matek dzieci nieprzystosowanych psychicznie okazało się naprawdę ,odrzucajacych” i choć setki z nich przewinęło się przez mój zakład, to tych, o których mowa nie było więcej niż palców

\footnotetext{
${ }^{86}$ L. Bobkowicz-Lewartowska, op. cit., s. 27.

87 Ibidem.

${ }^{88}$ C. H. Delacato, Dziwne, niepojęte: autystyczne dziecko, Warszawa 1995, s. 41.

${ }^{89}$ Ibidem.

90 Ibidem, s. 41-45.

91 T. Gałkowski, op. cit., s. 34.
} 
u jednej ręki [...] We współczesnej psychologii występuje bardzo silna tendencja do wyjaśniania przyczynowego tła schorzenia zwanego „, wczesna psychoza dziecięca” odrzuceniem dziecka przez matkę. Uważa się, że występująca od momentu urodzenia dziecka, a nawet nieco wcześniej niechęć matki do obdarowania dziecka miłościa sprawia, że staje się ono istota chora psychicznie. Taka nieświadoma ,wina” matki jest tylko hipoteza robocza, która bez względu na to czy jest prawdziwa czy też fatszywa spowodowata już olbrzymie szkody [podkr. K.O.] od czasu gdy zaczęto ja wysuwać i gdy stała się idea wyznawana w sposób sptycony i uproszczony ${ }^{92}$.

Cytowany wcześniej C. Delacato komentuje konsekwencje nurtu psychoanalitycznego jeszcze dotkliwiej: W 1971 roku dr L. Kanner przedstawił wyniki badań katamnestycznych, które objęty jedenaścioro dzieci opisanych przez niego $w$ pierwszym artykule o autyzmie. W tamtych latach nie stosowano prawie terapii, wiele z nich oddano więc do zakładów opieki. Kanner uważat, że umieszczenie dziecka w zakładzie opieki prowadziło do jego całkowitego wycofania się z kontaktów z otoczeniem. Badania katamnestyczne pokazywaty, że przez trzydzieści lat nie uczyniono specjalnych postępów w leczeniu, nie opracowano żadnej skutecznej terapii ${ }^{93}$.

Pojawia się w tym miejscu pytanie: dlaczego nurt psychoanalityczny stał się dominującym w wyjaśnianiu przyczyn autyzmu? W jaki sposób hipotetyczne koncepcje, niemające stabilnego potwierdzenia w nauce, zyskały popularność w szerokich kręgach naukowców, lekarzy, praktyków, a ostatecznie - samych rodziców ${ }^{94}$ ? Próbując odpowiedzieć na to pytanie, warto cofnąć się do pierwszego i fundamentalnego dla dalszych badań nad autyzmem artykułu L. Kannera z 1943 r.

Omówienia wymagają w tym miejscu dwa zagadnienia: statusu socjoekonomicznego rodziców, którzy rekrutowali się spośród intelektualistów ${ }^{95}$ oraz ich postaw wobec dziecka, opisanych przez L. Kannera jako „zimnych i sztywnych"96.

T. Gałkowski, powołując się na badania przeprowadzone w Middlesex w Anglii przez Lorne Wing w 1964 r., referuje, że autyzm częściej występuje „na terenach wysoko uprzemysłowionych” oraz „wśród rodzin posiadających wyższy status socjokulturalny" ${ }^{\prime 97}$. Zauważa jednak, że: rodzice inteligentni o wyższym standardzie socjokulturowym i lepiej sytuowani ekonomicznie mogli sobie pozwolić na szybka interwencje specjalistów i łatwiej dostrzegali wszelkie nieprawidłowościu u swych dzieci ${ }^{98}$.

Metaanaliza prac badawczych na temat statusu socjoekonomicznego rodziców, dokonana przez E. Schoplera (1979) wykazała, że opisywane związki są artefaktami - badacz wraz z zespołem zidentyfikował różnorodne przyczyny, które mogły doprowadzić do nadreprezentacji przypadków dzieci z autyzmem w rodzinach o wysokim statusie,

\footnotetext{
92 A. Brauner, Les enfant des confins, Paryż, 1976, s. 38-39; [cyt. za:] T. Gałkowski, op. cit., s. 34.

93 C. H. Delacato, op. cit., s. 154.

94 L. Bobkowicz-Lewartowska, op. cit., s. 27.

95 A. i F. Brauner, op. cit., s. 212.

96 Ibidem, s. 218.

97 T. Gałkowski, op. cit., s. 12.

98 Ibidem, s. 18.
} 
z czego najważniejsze to lepszy dostęp do informacji i centrów diagnostycznych oraz większe możliwości finansowe ${ }^{99}$.

Drugie zagadnienie - postawy rodziców 11 opisanych przez L. Kannera dzieci można również wyjaśnić, nie odnosząc się do patogennych cech osobowościowych samych rodziców, ale do sytuacji, w jakiej się znaleźli.

Warto, dla bliższego wyjaśnienia, przytoczyć kilka przykładowych opisów funkcjonowania rodziców. Jeden z ojców pracowat jako adwokat $i$ żył w stanie stałego przeciażenia praca zawodowa ${ }^{100}$, inny żył pogrążony w swojej pracy i nie przepadał za towarzystwem innych ludzi, pewna matka wszędzie dostrzegała patologię i była zajęta ciagle praca ${ }^{101}$.

Wiele z opisanych przez L. Kannera zachowań i postaw rodziców można - znacznie lepiej niż zaburzeniem ich osobowości czy brakiem prawidłowych postaw rodzicielskich - wyjaśnić syndromem wypalenia sil (burn-out syndrome), na który bardzo silnie narażeni są rodzice osób $\mathrm{z}$ autyzmem ${ }^{102}$. Zjawisko to jest obecnie dużo lepiej poznane i opisane, niż było to w czasie, gdy L. Kanner opublikował swoją pionierska pracę. Należy też pamiętać, że w owym czasie nie istniały praktycznie żadne realne formy wsparcia dla rodziny dziecka z zaburzeniem rozwoju i nie bez znaczenia pozostaje też fakt, że autyzm był wtedy zjawiskiem całkowicie niezrozumiałym, nie tylko dla rodziny, ale też dla samych specjalistów i badaczy.

Ich losy to pasmo ciagłych stresów, życie w izolacji i najczęściej bezskuteczne oczekiwanie na pomoc, która nie nadchodzi - pisał o sytuacji rodziny dziecka z autyzmem T. Gałkowski w 1980 r. ${ }^{103}$ Nie powinna więc dziwić kondycja psychiczna rodzin, które kilkadziesiąt lat wcześniej zjawiły się u L. Kannera.

\section{Wiedza neurorozwojowa o przyczynach autyzmu}

Wyniki badań z ostatnich 20 lat sugerują, że może być około 6 genów będących znaczącym czynnikiem ryzyka wystąpienia autyzmu, ponadto około 20-30 innych genów, mogących wpływać na głębokość zaburzenia. Są to geny regulujące rozwój i pracę układu nerwowego ${ }^{104}$.

W świetle współczesnych badań medycznych autyzm stanowi zaburzenie neurorozwojowe, rozwijające się na skutek kompilacji silnie dziedzicznej poligenowej predyspozycji genetycznej i środowiskowych czynników ryzyka - głównie teratogenów. W ten

99 L. Bobkowicz-Lewartowska, op. cit., s. 17.

100 A. i F. Brauner, op. cit., s. 202.

101 Ibidem, s. 201.

102 T. Gałkowski, Dziecko autystyczne w środowisku rodzinnym i szkolnym, Warszawa 1995, s. 80-81; L. Bobkowicz-Lewartowska, op. cit., s. 28-29.

103 T. Gałkowski, Usprawnienie dziecka..., s. 35.

${ }^{104}$ R. Wujcik, A. Porzycka, A. Witusik, T. Pietras, Neurorozwojowa hipoteza autyzmu, w: T. Pietras, A. Witusik, P. Gałecki (red), Autyzm..., s. 32. 
sposób jest też traktowane we współczesnej klasyfikacji $D S M-V^{105}$. Pod napływem licznych doniesień z dziedziny genetyki i neuropsychologii rozwojowej - choć wciąż nie do końca spójnych - domniemywane przez wiele lat psychogenne teorie etiologii tego zaburzenia nie dają się już utrzymać ${ }^{106}$.

Jak twierdzi Temple Grandin ${ }^{107}$, jest też prawdopodobne, że geny nieprawidłowości neurorozwojowych są skorelowane z genami szczególnych uzdolnień i ponadprzeciętnej inteligencji. T. Grandin przywołuje przypadki występowania szczególnych uzdolnień wśród osób z rodzin dzieci z zaburzeniami z kręgu autyzmu. Rzuca to nieco światła na przytoczoną wcześniej historię dzieci króla Krezeusa. Ponadto - jak już wspomniano rodziny o wyższym statusie socjoekonomicznym posiadają więcej informacji i mają większe możliwości zapewnienia swoim dzieciom szybkiej, prawidłowej diagnozy i terapii ${ }^{108}$. Doniesienia te podważają ponownie zasadność koncepcji ,zimnych i sztywnych” rodziców jako „winowajców” zaburzenia rozwoju dziecka. Jak pisze T. Grandin w swoich wspomnieniach ${ }^{109}$, ją również próbowano poddawać psychoterapii w nurcie psychoanalitycznym, z powodu rzekomych konfliktów z rodzicami, co - jak nietrudno się domyślić - nie przyniosło żadnych rezultatów. Rodzice wspierali ją i byli bardzo wrażliwi na jej potrzeby, co wyklucza deprywację emocjonalno-społeczną jako możliwą etiologię ${ }^{110}$.

Intensywny wyrost częstości diagnozowania autyzmu sprawił, że pojawiły się próby wyjaśnienia jego przyczyn czynnikami natury środowiskowej, takimi jak wzrost zanieczyszczenia środowiska, działania antybiotyków czy szczepionek. W istocie większość z nich nie została ostatecznie potwierdzona. Wzrost częstości diagnozowania autyzmu jest prawdopodobnie jedynie skutkiem zmian w klasyfikacji nozologicznej, która wywołuje tylko pozorny wzrost realnej zapadalności ${ }^{111}$.

Nie jest jednak wykluczone, że w patogenezie autyzmu działają nie tylko czynniki genetyczne $^{112}$. U około $50 \%$ dzieci prawdopodobne jest, że na ich rozwój wpłynęły oprócz czynników natury genetycznej oraz metabolicznej, również infekcje wirusowe w życiu płodowym, zatrucia, uszkodzenia okołoporodowe, niedotlenienia lub przetlenowania $\mathrm{w}$ inkubatorach. Ten zarys hipotetyczny ułatwia poszukiwanie dalszych uściśleń w badaniach nad etiologią autyzmu ${ }^{113}$.

105 J. Morrison, op. cit., s. 40.

106 L. Bobkowicz-Lewartowska, op. cit., s. 38.

107 T. Grandin, op. cit., s. 226.

108 L. Bobkowicz-Lewartowska, op. cit., s. 17.

109 T. Grandin, op. cit., s. 186.

110 J. Morrison, op. cit., s. 46.

111 M. Banasiak, A. Witusik, T. Pietras, P. Górski, Epidemiologia autyzmu, w: T. Pietras, A. Witusik, P. Gałecki (red.), Autyzm..., s. 11

112 A. Gruna-Ożarowska, Umyst niewspółodczuwający - neurobiologia autyzmu, w: B. Winczura (red.), Autyzm - na granicy zrozumienia, Kraków, 2009, s. 9.

113 K. Markiewicz, Możliwości komunikacyjne dzieci autystycznych, Lublin 2004, s. 23. 
Oczywiście wymienione czynniki są jedynie czynnikami ryzyka. Żadne badania nie dostarczają warunku rozwoju zaburzenia autystycznego, który byłby wystarczający i konieczny, ponieważ autyzm - jako zaburzenie neurorozwojowe - rozwija się zgodnie z dwoma zasadami neurorozwoju: zasadą multifinalności (dywergencją) i zasadą ekwifinalności (konwergencją) $)^{114}$. Oznacza to, że może istnieć wiele obrazów behawioralnych autyzmu spowodowanych podobnymi konfiguracjami czynników ryzyka. Jednocześnie zbliżone obrazy behawioralne zaburzenia mogą wywodzić się z odmiennych ścieżek rozwojowych.

Każdemu z objawów osiowych autyzmu można przypisać podłoże biochemiczne, anatomiczne, specyficzne zaburzenia aktywności pracy mózgu. Wiele z nich można ulokować w konkretnych jego obszarach ${ }^{115}$.

Należy przy tym wyraźnie zaznaczyć, że nie u wszystkich osób z autyzmem można odnaleźć te same dysfunkcje biologiczne. Przez lata badań prowadzonych w tym obszarze zgromadzono bardzo wiele danych na ten temat. Jest to wiedza ogromnie cenna, pozwalająca lepiej zrozumieć „,mechanizmy autyzmu” oraz odrzucić koncepcje o psychogennej etiologii tego zaburzenia ${ }^{116}$.

\section{Sila oddziaływania teorii psychoanalitycznych}

Dopiero trzecia wersja klasyfikacji DSM-III z 1980 r. zaklasyfikowała autyzm do całościowych zaburzeń rozwoju, formalnie odróżniając dzieci z autyzmem od psychotycznych lub schizofrenicznych ${ }^{117}$.

Całe pokolenia lekarzy i innych specjalistów były kształcone w nurcie psychoanalitycznym, czego konsekwencje dla rodzin dzieci autystycznych były i są druzgocące.

Badania przeprowadzone przez Petera Randala i współpracowników Przegląd zaspokojonych i niezaspokojonych potrzeb $w$ rodzinach dzieci autystycznych w 1996 r. dowodzą, jak głęboki ślad w świadomości rodziców dzieci z autyzmem pozostawiła psychoanalityczna indoktrynacja. Obrazują to podejrzenia rodziców dotyczące przyczyn zaburzenia ich dzieci:

$32 \%$ rodziców wskazuje za przyczynę traumatyczne doświadczenia dziecka we wczesnym dzieciństwie,

24\% doszukuje się własnych błędów w opiece nad dzieckiem,

$28 \%$ podejrzewa komplikacje ciąży lub podczas porodu,

$8 \%$ podaje za przyczynę czynniki genetyczne,

$12 \%$ odpowiada ,nie wiem”.

\footnotetext{
114 L. Bobkowicz-Lewartowska, op. cit., s. 38 - 39.

115 R. Wujcik, A. Porzycka, A. Witusik, T. Pietras, op. cit., s. 31-31.

116 Ibidem.

117 T. Gałkowski, Usprawnienie dziecka ..., s. 7.
} 
Zatrważający okazał się również stosunek krewnych do dziecka. Jak wynika z badań zespołu Randala krewni często komunikują osobliwe czy wręcz absurdalne opinie, a 30\% z nich wini rodziców za stan ich dziecka. Podobna część zarzuca rodzicom, że dziecko było zaniedbywane ${ }^{118}$.

Na gruncie polskim w 2004 r. Katarzyna Markiewicz ${ }^{119}$ przeprowadziła badania wśród studentów psychologii dotyczące ich wiedzy na temat przyczyn autyzmu. 34\% badanych wskazywało brak miłości rodziców - szczególnie matek - za przyczynę zaburzenia rozwoju dzieci. 32,8 \% podejrzewało zaburzenia osobowości rodziców, a 16,4\% złe postawy wychowawcze. Jakkolwiek badanie dotyczyło niewielkiej grupy studentów, wyniki te nie napawają optymizmem - obrazują, jak głęboko zakorzeniony jest naukowy mit autyzmu jako psychozy dziecięcej.

Fałszywa wiedza wygenerowała stereotyp psychotycznego dziecka kiwającego się w kącie z braku miłości rodziców. Stereotyp ten rezonuje do dzisiaj. Stanowi on efekt mozolnej pracy wielu badaczy, którzy w zwartym kolektywie myślowym zbudowali wzorowy naukowy mit.

\section{Kolektyw myślowy i mit naukowy}

Praca L. Kannera nie powstała w intelektualnej próżni - pojawiła się w określonym kontekście i klimacie naukowym, tworzonym przez specjalistów zajmujących się ludzką psychiką i zachowaniem. Odbiorcami i pierwszymi interpretatorami pracy pediatry był więc - jakby to określił Ludwik Fleck - pewien myślowy kolektyw wyposażony w swoisty, ukształtowany historycznie styl myślowy ${ }^{120}$. Choć kolektyw myślowy składa się z jednostek, to nie jest on ich prosta suma. Jednostka nie ma nigdy - lub prawie nigdy świadomości kolektywnego stylu myślenia, który prawie zawsze wywiera bezwzględny przymus na jej myślenie $i$ wbrew któremu niczego właściwie nie można pomyśleć ${ }^{121}$.

$\mathrm{W}$ intensywnie rozwijanym w poł. XX w. nurcie psychoanalitycznym niemożliwym niemal było zbudowanie innej powszechnie akceptowanej koncepcji etiologii zaburzenia przypominającego schizofrenię (choć sam L. Kanner od początku swych rozważań odróżniał opisane przez siebie zaburzenie od schizofrenii). W ujęciu L. Flecka obserwacja jest uzależniona od stylu myślowego obecnego we wspólnocie myślowej, tym samym myślenie stanowi czynność społeczną ${ }^{122}$. System przekonań, jakim dysponuje wspólnota, stawia opór wszystkiemu co mu przeczy i jest to nie tylko opór bierny, ale także aktywny sposób działania. Jak pisze L. Fleck: To co jest niezgodne z systemem pozostaje niezauważone lub pominięte milczeniem [...] lub tė̇ dokonuje się ogromnego wysiłku, aby wy-

\footnotetext{
118 P. Randal i J. Parker, Autyzm: jak pomóc rodzinie, Gdańsk 2004, s. 97.

119 K. Markiewicz, op. cit., s. 57.

${ }^{120}$ L. Fleck, Powstanie i rozwój faktu naukowego, Lublin 1986, s. 68.

121 Ibidem, s. 70.

${ }^{122}$ Ibidem, s. 130.
} 
thumaczyć, że wyjątek nie jest sprzeczny z systemem. Wbrew uzasadnieniom, sprzecznym poglądom widzi się, opisuje i nawet przedstawia stany rzeczy, które odpowiadaja panującym poglądom [podkr. K.O.], tzn. jakby stanowia ich realizację ${ }^{123}$.

Opis L. Kannera - jeśli miał zostać zauważony - musiał zostać zinterpretowany w kontekście psychoanalitycznym, a doniesienia sugerujące inne wyjaśnienia - np. mikrouszkodzeń mózgu - spotykały się z oporem środowisk naukowych, o czym pisał już C. Delacato: Wspaniała idea, być może nowy sposób, żeby pomóc dzieciom, podniecenie odkryciem! Powinienem byt być zachwycony, ale nie byłem [...] Ten pomyst byt zbyt inny. Odchodził za daleko od tego, co przyjęto wcześniej. Wyprowadzi z równowagi wszystkich, którzy przez całe życie patrzyli na te dzieci z punktu widzenia psychologii, zamiast dostrzegać ich problemy percepcyjne i neurologiczne ${ }^{124}$.

Wydaje się, że psychoanalityczne teorie etiologii autyzmu urosły do rangi mitu naukowego. Mit - oprócz wielu innych funkcji - dostarcza „nieempirycznych realności” jak ujmuje to Jaromir Jeszke ${ }^{125}$. Mit utwierdzony w nauce poprzez ,zaspokajanie potrzeb niemożliwych do zaspokojenia w inny sposób" ułatwia jej społecznie przypisane zadanie dochodzenia do prawdy o świecie, czyli zaspokajania potrzeb poznawczych. Prawda ta jednak będzie zniekształcona. Jest to jedna $\mathrm{z}$ możliwych przyczyn przyjęcia przez środowiska naukowe koncepcji, niemających potwierdzenia w badaniach empirycznych ${ }^{126}$.

Drugą z potencjalnych przyczyn utrwalenia się tych poglądów może stanowić autorytet ich twórców. Społeczeństwo ma skłonność do mniej lub bardziej bezkrytycznego przyjmowania naukowych opinii tylko dlatego, że padty one z ust wykształconych osób - zauważa Luc Bürgin ${ }^{127}$. Dodaje również, że: zawodowe pojedynki autorytetów tocza się zwykle przy drzwiach zamkniętych i przeciętny człowiek nic o nich nie wie. Tak byto zawsze, ale $w$ rezultacie społeczeństwo - a z braku krytyki z zewnątrz nierzadko także sami naukowcy - utożsamia naukowe modele z dokładnym odbiciem rzeczywistości ${ }^{128}$. Sytuacja ta nie jest korzystna dla rozwoju nauki, a także może stanowić przyczynę fałszywego wyobrażenia społecznego o świecie.

Mit naukowy jest tu rozumiany według definicji Jerzego Topolskiego, jako rodzaj przeświadczenia, które nie poddaje się, badź nie jest poddawane weryfikacji i niezmiennie trwa $w$ świadomości badaczy lub $w$ ich tekstach ${ }^{129}$.

Jak ostrzega Leszek Kołakowski mit może rozrastać się jak tkanka nerwowa, może zmierzać do zastapienia wiedzy pozytywnej, prawa, może próbować zagarnać przemoca wszystkie prawie obszary kultury, może obrastać despotyzmem, terrorem, kłamstwem ${ }^{130}$.

\footnotetext{
123 Ibidem, s. 56.

124 C. H. Delacato, op. cit., s. 68-69.

125 J. Jeszke, Mity polskiej historiografii nauki, Warszawa 2007, s. 9.

126 Ibidem, s. 11.

127 L. Bürgin, Błędy nauki. Zapomniani geniusze - ich droga przez męke, Warszawa 1998, s. 7.

128 Ibidem.

129 J. Jeszke, op. cit., s. 12.

${ }^{130}$ L. Kołakowski, Obecność mitu, Wrocław 1994, s. 48-49.
} 
Nie ma powodu, by uznać, że słowa wybitnego filozofa nie mogą dotyczyć historii nauki ${ }^{131}$. Tym samym historii badań społecznych i zawartych w niej badań nad autyzmem.

Relacja pomiędzy mitem a nauką wydaje się być zagadnieniem pozornie paradoksalnym - to, co mityczne jest bowiem usytuowane poza nauką, dotyczy innych niż naukowa rodzajów wiedzy, jest podatne na wpływy kulturowe. Nauka od zawsze miała odznaczać się niezależnością od takich wpływów. Z powodów radykalnej odmienności tych dwóch sposobów postrzegania rzeczywistości, bardzo długo nie było wśród historyków nauki zgody na miejsce dla mitu w tak „szlachetnej” dziedzinie kultury jaką jest nauka ${ }^{132}$.

Jednak - jak wprost wskazuje Alina Motycka - mit zaspokaja pewien rodzaj potrzeb ludzkich, których nauka zaspokoić nie może, toteż jego obecność w kulturze jest niezbywalna, a scjentystyczna wizja petnej demitologizacji nauki - utopijna ${ }^{133}$.

Stanisław Anderski ${ }^{134}$ - choć nie posługuje się pojęciem mitu - barwnie przedstawia mechanizm jego powstawania w naukach społecznych przez porównanie badaczy ludzkiego zachowania do czarowników: Ponieważ jego [badacza] teorie sa często trudne do sprawdzenia, ludzie chca, aby im mówit to, co chca ustyszeć [...]. Dlaczego miałby on opierać sie groźbom i pokusom, skoro w jego dziedzinie tak trudno jest cokolwiek udowodnić, a zaspokajanie własnych zachcianek, granie na ludzkich emocjach, a nawet świadome kłamstwa moga pozostać bezkarne? Jego dylemat wyrasta jednak z trudności odwrotu - przekroczywszy granicę trudno jest już przyznać, że zmarnowało się lata w pościgu za widmami lub czerpało korzyści z naiwności ludzi. Aby uciszyć watpliwości, niepokoje i poczucie winy, idzie się po linii najmniejszego oporu i rozbudowuje w nieskończoność sieć fikcji lub klamstw [podkr. K.O.], coraz głośniej mówiąc przy tym o dą̇eniu do obiektywności i poszukiwaniu prawdy ${ }^{135}$.

Powstanie, rozwój i ekspansja oraz silny opór przed zmianami teorii o psychogennej etiologii autyzmu mają wszelkie znamiona zmitologizowanego wytworu bardzo specyficznego i wąskiego kolektywu myślowego, na co dobitnie wskazują słowa T. Gałkowskiego: $w$ tej powszechnej tendencji do obciążania rodziców zaznacza się nie podejście psychoanalityczne, lecz jest to dość charakterystyczne zjawisko społeczne spowodowane obecnym stanem wiedzy w tej dziedzinie. Specjaliści bezskutecznie starają się wyjaśnić to, co dotąd pozostaje niewyttumaczalne i tworza pseudo-naukowe grono, wielkich czarowników”. Nikt nie zajmuje się weryfikacją tej hipotezy, a jej wyznawcy przyoblekaja się w czerwone szaty prokuratorów [podkr. K.O.] ${ }^{136}$.

\footnotetext{
131 J. Jeszke, op. cit., s. 19.

132 Ibidem, s. 20.

133 A. Motycka, Rozum i intuicja w nauce, Warszawa 2005, s. 148-149.

134 S. Anders, Czarnoksięstwo w naukach spolecznych, Warszawa 2002, s. 33.

135 Ibidem.

136 T. Gałkowski, Usprawnienie dziecka ..., s. 35.
} 


\section{Głos od wewnątrz - objawienie autyzmu wysokofunkcjonującego}

Wielką szansą na zmianę postrzegania autyzmu może stanowić głos wysokofunkcjonujących osób z autyzmem. Spośród tych osób najbardziej znaną na świecie jest T. Grandin - doktor nauk o zwierzętach, profesor na Uniwersytecie w Colorado. Jej książka Myślenie obrazami ukazała się w 1986 r., jako pierwsza relacja na temat autyzmu „od wewnątrz". Jaki pisze Oliver Sacks w przedmowie tej niezwykłej publikacji: ksiażka bardzo niezwykła, nowatorska $i$ w pewnym sensie niemożliwa ${ }^{137}$. Opinia ta nie jest w żadnym razie przesadzona, ponieważ $\mathrm{w}$ tym czasie panował pogląd, że osoby $\mathrm{z}$ autyzmem nie mają „wnętrza”, a jeśli nawet, to nie sposób do niego w żaden sposób dotrzeć. Głos Temple Grandin dociera do nas z miejsca, z którego nigdy żaden głos nie rozbrzmiewat, któremu wręcz nie przypisywano prawdziwego bytu. T. Grandin nie przemawia tylko we własnym imieniu, ale także tysięcy innych uzdolnionych wybitnie autystycznych ludzi. Było to doprawdy objawienie pisze Sacks ${ }^{138}$.

Postać T. Grandin nie jest odosobnionym wyjąatkiem. Warto w tym miejscu przywołać urodzoną w Australii Donę Wiliams, która zdobyła miejsce na uniwersytecie w czasach, gdy pojęcie autyzmu niemal nie było jeszcze znane. W swojej autobiograficznej książce Nikt nigdzie - przetłumaczonej na 14 języków - opisuje swoje zmagania w nieustającej konfrontacji własnego postrzegania świata z niezrozumieniem otoczenia: Kiedyś podwoziłam do domu pewna dziewczynę z uniwersytetu. Gdy przejeżdzaliśmy obok szkoły specjalnej, do której chodziłam jako małe dziecko, pokazałam jej, że tam się uczyłam.

- Niemożliwe - powiedziała. - To jest szkoła specjalna.

- To znaczy? - Spytałam.

- Szkoła dla dzieci specjalnej troski - wyjaśniła. - Moja mama pracuje tam jako logopeda.

- Może coś się zmieniło - przypuściłam naiwnie.

- Nie, to zawsze byla szkoła specjalna - odparta. - Możesz spytać moja mamę.

Bryn i ja leżeliśmy wyciagnięci na trawie. Powiedziałam mu, co mówiła ta dziewczyna.

- Ja też chodziłem do szkoty specjalnej - zwierzyt się Bryn. - Rodzice wysyłali mnie z domu, bo myśleli, że jestem wariatem.

Opowiedział mi, jak spędzat czas $w$,,domu opieki” $i$ że miat problemy $w$ porozumiewaniu się z ludźmi. Jego rodzice sądzili, że może mieć schizofrenię $e^{139}$.

Niemiecki pisarz i filmowiec Axel Brauns, odwołując się do wspomnień z dzieciństwa i młodości przedstawia niezwykłe spostrzeganie, rozumowanie i zachowania osoby $\mathrm{z}$ autyzmem w swojej książce Barwne cienie i nietoperze. Życie w autystycznym świecie: Niektórzy ludzie z autyzmem wioda życie $w$ ciszy, zamknięci $w$ sobie, inni szaleja, bo rzeczywistość ich przytłacza. [...] Niektórzy ludzie z autyzmem chętnie się śmieja

\footnotetext{
137 T. Grandin, op. cit., s. 11.

138 O. Sacks, Przedmowa, w: T. Grandin, op. cit., s. 11.

139 D. Williams, Nikt nigdzie - niezwykła autobiografia autystycznej dziewczyny, Warszawa 2005, s. 109.
} 
i dużo gadaja, inni są raczej rzeczowi i małomówni. Niektórzy ludzie z autyzmem rozpaczają z powodu przygnębiajacych myśli, inni zasiedlają słoneczna stronę życia ${ }^{140}$.

Nie należy oczywiście doszukiwać się w każdym autystycznym dziecku ukrytego geniuszu. Dotychczasowe badania wskazują, że u znacznej części osób z autyzmem współwystępuje niepełnosprawność intelektualna, a część z nich nigdy nie opanowuje mowy werbalnej. Trudno wskazać dokładną częstotliwość występowania tych zaburzeń - pewne badania wskazują, że dotyczą odpowiednio 75\% (niepełnosprawność intelektualna) i 50\% (brak mowy werbalnej) ${ }^{141}$ osób z autyzmem. Bardziej aktualne dane szacunkowe - pochodzące z badań przeprowadzonych w Polsce - wskazują, że jedynie około połowa (47\%) osób ze zdiagnozowanym autyzmem, ma również diagnozę niepełnosprawności intelektualnej ${ }^{142}$. W literaturze przedmiotu można znaleźć także różne wyniki badań w zakresie braku zdolności posługiwania się mową, np. wskazujące, że tylko 1/3 osób z autyzmem nie nabywa języka werbalnego ${ }^{143}$.

Dane te mogą w dalszym ciągu ulegać zmianom ze względu na coraz wcześniejsze diagnozowanie autyzmu - nawet u bardzo małych dzieci z grupy ryzyka. Wczesna terapia w zakresie umiejętności komunikacyjnych powoduje, iż rozwój umysłowy postępuje $\mathrm{u}$ wielu dzieci w miarę sprawnie, a ryzyko niepełnosprawności intelektualnej staje się coraz mniejsze ${ }^{144}$.

Oznacza to, że znaczna część osób z autyzmem - szczególnie dotyczy to małych dzieci - ma duże szanse na opanowanie mowy werbalnej i prawidłowy rozwój intelektualny. T. Grandin pisze, że w wieku 6 lat nie mówiła, a jej zachowanie było głęboko zaburzone. Przynajmniej jedno dziecko na 10 może być dzieckiem wysokofunkcjonującym $^{145}$, a przykład T. Grandin świadczy o tym, że nigdy nie wiadomo które - niekoniecznie tylko te, które w danej chwili przejawiają ku temu predyspozycje ${ }^{146}$.

I o tym muszą pamiętać specjaliści, a oprócz rzetelnej wiedzy o deficytach poznawczych osób z autyzmem powinni mieć też pewną szczególną zdolność - słuchania głosu ich samych, głosu, który - wbrew temu co latami sądzono - istnieje: Satysfakcji dostarcza mi to, co powoduje realna zmiane $w$ realnym świecie - potrzeba nam tego więcej, a o wiele mniej abstrakcji ${ }^{147}$.

140 A. Brauns, Barwne Cienie i nietoperze. Życie w autystycznym świecie, Poznań 2009, s. 19.

141 T. Pietras, A. Witusik, op. cit., s. 20.

${ }^{142}$ M. Płatos (red.), Ogólnopolski Spis Autyzmu Sytuacja młodzieży i dorosłych z autyzmem w Polsce, Warszawa 2016, s. 77.

143 B. Kaczmarek, Nie jak, ale dlaczego? O własnym języku dzieci z autyzmem, w: B. Winczura (red.), Autyzm - na granicy zrozumienia, Kraków 2009, s. 110.

${ }^{144}$ J. Grochowska, Wczesne diagnozowanie autyzmu z pomoca kwestionariusza CHAT, w: T. Gałkowski, J. Kossewska (red.), Autyzm wyzwaniem naszych czasów, Kraków 2001, s. 46.

145 B. Kaczmarek, op. cit., s. 110.

146 T. Grandin, op. cit., s. 89.

${ }^{147}$ (TED2010, Temple Grandin: Światu potrzeba umysłów różnego rodzaju, http://www.ted.com/talks/ lang/pl/temple_grandin_the_world_needs_all_kinds_of_minds.html, [10.11.2012]) 


\section{Bibliografia}

Anders S., Czarnoksięstwo w naukach spolecznych, Warszawa 2002.

M. Banasiak, A. Witusik, T. Pietras, P. Górski, Epidemiologia autyzmu, w: T. Pietras, A. Witusik, P. Gałecki (red.), Autyzm - epidemiologia, diagnoza i terapia, Wydawnictwo Continuo, Wrocław 2010.

Bobkowicz-Lewartowska L., Autyzm dziecięcy - zagadnienia diagnozy i terapii, Kraków 2000.

Brauner A. i F., Dziecko zagubione w rzeczywistości: historia autyzmu od czasów baśni o wróżkach. Fikcja literacka i rzeczywistość kliniczna, Warszawa 1988.

Brauns A., Barwne Cienie i nietoperze. Życie w autystycznym świecie, Poznań 2009.

Bürgin L., Błędy nauki. Zapomniani geniusze - ich droga przez mękę, Warszawa 1998, Wydawnictwo PROKOP.

Delacato C. H., Dziwne, niepojęte: autystyczne dziecko, Warszawa 1995.

Fleck L., Powstanie i rozwój faktu naukowego, Lublin 1986.

Gałkowski T., Usprawnienie dziecka autystycznego w rodzinie, Warszawa 1980, Polskie Towarzystwo Walki z Kalectwem.

Gałkowski T., Dziecko autystyczne w środowisku rodzinnym i szkolnym, Warszawa 1995, Wydawnictwo Szkolne i Pedagogiczne.

Grandin T., Myślenie obrazami oraz inne relacje z życia z autyzmem, Warszawa 2006.

Grochowska J., Wczesne diagnozowanie autyzmu z pomoca kwestionariusza CHAT, w: Gałkowski T., Kossewska J. (red.), Autyzm wyzwaniem naszych czasów, Kraków 2001, Wydawnictwo Naukowe Akademii Pedagogicznej.

Gruna-Ożarowska A., Umyst niewspółodczuwający - neurobiologia autyzmu, w: B. Winczura (red.), Autyzm - na granicy zrozumienia, Kraków 2009, Impuls.

Jeszke J., Mity polskiej historiografii nauki, Warszawa 2007.

Kaczmarek B., Nie jak, ale dlaczego? O własnym języku dzieci z autyzmem, w: Winczura B. (red.), Autyzm - na granicy zrozumienia, Kraków 2009, Impuls.

Kołakowski L., Obecność mitu, Wrocław 1994.

Markiewicz K., Możliwości komunikacyjne dzieci autystycznych, Lublin 2004.

Morrison J., DSM-5 bez tajemnic. Praktyczny Przewodnik dla klinicystów, Kraków 2016, Wydawnictwo Uniwersytetu Jagiellońskiego .

Motycka A., Rozum i intuicja w nauce, Warszawa 2005.

Płatos M. (red.), Ogólnopolski Spis Autyzmu Sytuacja młodzieży i dorosłych z autyzmem w Polsce, Warszawa 2016, Stowarzyszenie Innowacji Społecznych „Mary i Max”.

Pietras T., Witusik A., Autyzm - pozycja nozologiczna, charakterystyka kliniczna i diagnoza, w: Autyzm - epidemiologia, diagnoza i terapia, red. Pietras T., Witusik A., Gałecki P., Wrocław 2010.

Randall P., Parker J., Autyzm: jak pomóc rodzinie, Gdańsk 2004.

Skórczyńska M., Wczesne diagnozowanie autyzmu - perspektywy i dylematy, w:, Autyzm - na granicy zrozumienia, Winczura B. (red.), Kraków 2009, Impuls.

Szydziak M., Ewolucja poglądów na przyczyny autyzmu, w: Marzec D., Banasiak A. (red.) Dziecko z autyzmem: rozważania teoretyczne, doniesienia z badań, Częstochowa 2005, Akademia im. Jana Długosza.

Talarowska M., Florkowski A., Gałecki P., Zboralski K., Badanie psychologiczne w autyzmie, w: Pietras T., Witusik A., Gałecki P. (red.), Autyzm - epidemiologia, diagnoza i terapia, Wrocław 2000, Wydawnictwo Continuo.

Williams D., Nikt nigdzie - niezwykła autobiografia autystycznej dziewczyny, Warszawa 2005.

Winczura B., Zaburzenia ze spektrum autystycznego: różnicowanie diagnostyczne, w: Pedagogika specjalna - koncepcje i rzeczywistość, T. 6, Wyzwania wspótczesnej pedagogiki specjalnej- 
praktyka edukacyjna i rewalidacyjna, Żółkowska T., Ostapiuk B., Wlazło M. (red.), Szczecin 2000, Wydawnictwo Zapol.

Wójcik R., Porzycka A., Witusik A., Pietras T., Neurorozwojowa hipoteza autyzmu, w: Autyzm epidemiologia, diagnoza i terapia, red. Pietras T., Witusik A., Gałecki P., Wrocław 2010.

TED2010, Temple Grandin: Światu potrzeba umysłów różnego rodzaju, http://www.ted.com/talks/ lang/pl/temple_grandin_the_world_needs_all_kinds_of_minds.html, 2012 [10.11.2012]. 